\title{
My brother's keeper: Transcendent leadership lessons learned from an inner-city program for fatherless, adolescent boys
}

\author{
Eric Buschlen, Ed.D. \\ Associate Professor, \\ Educational Leadership \\ Central Michigan University \\ Tzu-Fen Chang, Ph.D. \\ Assistant Professor, \\ Human Environmental Studies \\ Central Michigan University \\ Dena R. Kniess, Ph.D. \\ Assistant Professor, \\ Counselor Education and College Student Affairs \\ University of West Georgia
}

\begin{abstract}
Providing leadership education for young men growing up without their father, through a structured curriculum and mentoring program, should enhance their development. To examine this, the authors interviewed adult alumni who participated as adolescents in a cohort-based, sixmonth leadership program. Interviews outlined several key themes: once served by others the young men desired to serve their community, choosing an authentic leadership educator matters, program mentors inspired positive life changes, and the learned leadership lessons transcended the setting and the curriculum. This qualitative project examined the efficacy of a youth leadership development program by interviewing past participants. This research outlined how service to others can inspire more service and that leadership education has the potential to alter lives, and in this case, even save lives.
\end{abstract}

\section{Introduction}

A leader needs many experiences to develop effective leadership skills. Similarly, adolescent boys need many experiences to develop into well-rounded men. Growing up without both parents in the home can leave lasting negative imprints on children including anger, fear, aggression, depression, and despair (American Academy of Pediatrics AAP, 2003; Bojuwoye \& Sylvester, 2014; Bryant \& Zimmermann, 2003; Carter-Haith, 2008). Children may often accept their situation as "normal." However, they still tend to feel dissatisfied with their status emotionally, financially, spiritually, and socially (Bojuwoye \& Sylvester, 2014). Clearly, the amount of time parents spend with children matters to personal growth and development (AAP, 2003; Hancock, Dyk, \& Jones, 2012; Rehm, 2014; Rose, 2010). While more parents work fulltime, many adolescents become part of after-school programs, team sports, clubs and organizations, and so on, while other adolescents may seek employment. Still, other adolescents 
seek a familial relationship in settings inclusive of drugs, alcohol, and crime. To combat the latter issue, many rural and urban settings since the 1990's have created youth mentoring and leadership programs (Bean, Whitley, \& Gould, 2014; Bethea, 2012; Hicks Peterson, Dolan, \& Hanft, 2010; Swigert \& Boyd, 2010; Rose, 2010; Wisniewski, 2010).

Schools and community programming efforts provide many opportunities for adolescents to develop and learn leadership both in and out of a classroom setting (Eva \& Sendjaya, 2013; Ricketts \& Rudd, 2002). Eccles, Barber, Stone, and Hunt (2003) showcased after-school programs as means to promote continued school-based engagement, to curb social/ethnic inequalities in accomplishment, to prepare students for a skill-based work force, and to help decrease the amount of unsupervised time. During adolescent years, students begin to develop their personal identity and their leadership identity through these shared experiences, events, and activities (Komives \& Dugan, 2014). As youth leadership programs and after-school programs continue to emerge around the nation (Brumbaugh \& Cater, 2016), a need exists to understand the lasting impact of these programs on participants. It is important to understand what, if any, leadership knowledge or skills (e.g. service to others, civic engagement, and/or mentoring) are retained and then implemented back into communities (Horstmeier \& Ricketts, 2009; Hancock, Dyk, \& Jones, 2012).

The purpose behind the current project was to capture experiences from alumni who completed a community-based leadership education program found in a mid-western, urban setting dedicated to helping fatherless boys develop into lifelong leaders. Specifically, this project will outline how an after-school program can act as a lasting model of positive social change for inner-city youth. The goal of the research was to demonstrate the impact of leadership education provided to these young men and to understand the efficacy of the program. The social change model of leadership (SCML) was used to both frame questions and to examine participants' individual, team, and community development (HERI, 1996). While the curriculum was examined by the research team, it was not the focus of this project.

The research question driving this project is: How do the reflective stories from alumni highlight the program's efficacy and ongoing, lasting impact? While previous youth leadership research has studied programmatic outcomes through quantitative methods (Oliver et al, 2011), this project uniquely examined personal narratives framed through the lens of the SCML (HERI, 1996). Using the SCML as a framework for both the interview questions and for the examination of data allowed the research team to uncover key components of social change and to understand participant engagements.

The following section will review literature on adolescent development, youth leadership education, mentorship, and service to others followed by a brief explanation of the SCML. A subsequent section will examine the methodology, followed by results, discussion, and implications.

\section{Review of Literature}

Developing leadership skills in adolescents represent a crucial strategy that should be endorsed, accepted, and practiced by schools and after-school programs (Hine, 2012). For 
fatherless boys, fostering their leadership identity may enhance their community involvement, which has been identified as a key asset protecting them from maladjustment in various arenas, including externalizing behavior, and social and academic adjustment (Oman, Vesely, \& Aspy, 2005). Hastings, Barrett, Barbuto, and Bell (2011) showcased that action taken by youth in leadership trainings created both connections and common ideas to drive future social success. This pushes leadership educators beyond a normative educational experience to develop teachings focused on awareness, civic engagement, multiculturalism, ethics, and service to others (Komives, Owen, Longerbeam, Mainella, \& Osteeen, 2005). In addition, educators should create opportunities for more service-based projects to provide ongoing exposure to the practice of compassionate, servant leadership (Arnold \& Welch, 2007; Berger \& Milem, 2002; Buschlen $\&$ Guthrie, 2014).

Leadership education has the potential to prepare adolescents for occupations and permits youth to understand what it means to be an active citizen who is engaged in their community (Sessa, Morgan, Kalenderli, \& Hammond, 2014). Leadership and character development of students should not be viewed as a terminal, one-time event (Mumford, Marks, Connelly, Zaccaro, \& Reiter-Palmon, 2000) as leadership is a process which evolves throughout one's life (Polk, 2013; Priest \& Donley, 2014; Rose, 2010; Rosch, Boyd, \& Duran, 2014).

There is a need for youth leadership training to help connect adult leadership theories with youth leadership development (MacNeil, 2006). For a community-based organization or school setting to ensure seamless leadership learning (Buschlen \& Guthrie, 2014), a need exists to more deeply understand both the individual and collective outcomes found in youth leadership education experiences. While there is more research available regarding the capacity of adults to learn leadership, the examination of youth leadership learning has been limited (Brumbaugh \& Cater, 2016; Geurin, Oliver, Gottfried, Gottfried, Reichard, \& Riggio, 2011; Ricketts \& Rudd, 2002). Many youth leadership programs are brief, fall short of collecting formalized data, and/or operate without learning outcomes (Higham, Freathy, \& Wegerif, 2010; Larson \& Tran, 2014; MacNeil, 2006).

Leadership is now viewed as a skill that can be taught and learned (Buschlen \& Dvorak, 2011; Dugan \& Komives, 2007). Formal, curricular-based leadership education has emerged in recent decades, but growth has been slow both at the adolescent, high school, and collegiate level (Owen, 2012; Woodland, 2012). Generally speaking, leadership educators tend to provide experiences both in and out of a classroom setting to help expand leadership efficacy through service, group projects, and formalized training often followed by personal reflection - either spoken or written (Arnold \& Welch, 2007; Astin, 1993; Berger \& Milem, 2002; Buschlen \& Reusch, 2016; Komives, Lucas, McMahon, 1998; Mumford \& Manley, 2003). Hine (2014) argued that middle and secondary students have the potential for leadership, but proper training is vital and often missing. Adolescents, like adults, develop leadership competencies at different stages and therefore should be given the opportunity to explore various ways to learn about their skills in both formal and informal trainings (Conner, \& Strobel, 2007) as they manage the process of developing a leadership identity (Komives \& Dugan, 2014). Higham, Freathy, and Wegerif (2010) explained that youth leadership programs are essential elements to engrain character in young people while at the same time preparing them to face life's challenges. 
Youth Leadership Development. Adolescents understand the need for effective leadership and have the capacity to learn to be leaders (Anderson \& Kim, 2009; Daugherty \& Williams, 1997; Eva \& Sendjaya, 2013). During the adolescent years, leadership training takes on many forms: service to others, participation in athletics and/or other co-curricular organizations, church groups, community programs, and potentially fundraising (Anderson \& Kim, 2009), while other programs are more structured and based on an actual leadership curriculum (Daugherty \& Williams, 1997; Kress, 2006). Active participation often leads to skill development in the areas of communication, problem solving, empathy, group interactions, and a stronger sense of self-identity (Anderson \& Kim, 2009; Larson, Walker \& Pearce, 2005; Priest \& Donley, 2014) which are all components of the SCML (HERI, 1996).

While teaching formalized leadership skills in a classroom setting has slowly evolved in the higher education arena (Eich, 2008, Owens, 2012), the concepts of teaching leadership to adolescents is based more in experiential training (e.g. student ran events/programs, completing tasks, holding a title) versus learning to lead others (Guthrie \& Thompson, 2010; Libby, Sedonaen, \& Bliss, 2006; Rehm, 2014). This drawback tends to diminish the value and quality of youth leadership development (Eva \& Sendjaya, 2013; Horstmeier \& Ricketts, 2009). Still, active participation in any sort of program related to the school or community has shown to decrease problematic behaviors such as fighting, stealing, and truancy while increasing positive ties to both school and community (Brumbaugh \& Cater, 2016; Hansen, Larson, \& Dworkin, 2003; Lapierre, Naidoo, \& Bonaccio, 2012). The leadership lessons learned by adolescents are self-development, tenacity, personal skills, social networking, relationship development/maintenance, and relating skills (Hansen, Larson, \& Dworkin, 2003; Libby, Rosen, $\&$ Sedonaen, 2005). The goal of most youth leadership programs is to transform an adolescent into one ready to combat life's challenges while being ready to lead in his or her community (O’Donoghue \& Strobel, 2007). The most transformational programs can view this change over a span of time as the adolescent develops into an adult (Reichard et al, 2011).

Youth Leadership Development for an At-Risk Population. In a mostly urban setting, similar to the population studied in this project, youth leadership development research addresses additional societal gains for participants (Bethea, 2012; Swigert \& Boyd, 2010). Youth in urban programs outlined a future commitment to positive social action after participating in a six-week summer course (Bethea, 2012). Another program reduced peer aggression and bullying, along with sexual aggression (Connolly et al, 2015) and still another increased reciprocal respect for others (Jackson, Sealey-Ruiz, \& Watson, 2014). Other programs seek to reduce aggression of low-income, high-risk minority youth (Leff, et al, 2014). Together, youth leadership programs have the potential to protect fatherless boys from maladjustment and facilitate successful transitions from adolescent learner to adult leader (Oman et al., 2005).

In short, youth leadership education takes many shapes and sizes. There may be an overarching, common theme to "develop future leaders," but youth leadership programs tend to be unique and specialized. More needs to be known about the protocols, processes, and signature pedagogies which create effective leadership trainings. This will increase efficacy for special student populations such as inner-city youth (Eccles, Barber, Stone, \& Hunt, 2003) and in this case, those adolescents developing in the absence of a father. 
Fatherlessness. According to the United States Census (2015), approximately 27\% of boys under the age of 18 live without their biological fathers in the home. When compared to those living in a two-parent household, fatherless boys are at higher risk for psychological and social maladjustment (e.g., depression and identity confusion), academic maladjustment (e.g., low academic achievement and delinquency), health risk behaviors (e.g., smoking, alcohol consumption, and having sexual intercourse), and externalizing behavior problems (e.g., weapon-related violence and fighting) (Bishop \& Lane, 2000; Blundell, 2002; Blum et al., 2000; Brown \& Rinelli, 2010; DeBell, 2007; Oman et al., 2005).

This high risk for maladjustment among the fatherless boys is explained by paternal absence (Curran, 2003). For example, fatherless boys in general have problems in the consolidation of gender identity since they lack a father as a male role model in their family to learn the meaning of being a man (Bishop, 2000). Additionally, boys with the paternal absence tend to react with a feeling of rage toward the father's desertion (Bishop, 2000; Blundell, 2002). To cope, some boys suppress emotions and develop internal (psychological) problems later, while others use externalizing approaches, such as fighting or weapon-related violence as an escape. The high likelihood for maladjustment among these boys is likely due to factors that are related to fatherlessness, such as socioeconomic stress of the single household and parental conflict prior to or after divorce or abandonment (Curran, 2003).

Although fatherless boys in general are at higher risk for maladjustment, some of them are protected from maladjustment because they have assets that serve as buffers, such as nonparental adult mentors, peer role models, enhanced communication abilities, sense of responsibility, and positive community involvement in co-curricular programs (Oman et al., 2005). Given that fatherless boys with assets tend to be buffered from maladjustment, providing the population with interventions that aim to equip boys with these assets - such as through community-based youth leadership and mentoring programs - provide likely benefits for them and for society. For example, the Big Brothers/Big Sisters program matches a fatherless boy (or girl) with an adult who provides life skill mentoring aimed at benefiting his or her overall development. Research has shown that these programs are beneficial for fatherless boys, such as maturation of male identity, stronger peer relations, improved academic achievement, and selfesteem/worth (Bruce, 1973; Frecknall \& Luks, 1992; Saintonge, 1987). Through structured mentoring programs, participants can transfer these learned skills to the college and community environment. In a qualitative study of 19 minority students at a predominantly White institution (PWI), Palmer, Maramba, and Homes (2011) found that supportive relationships with peers and faculty, involvement in student organizations, and self-accountability supported student success and retention in college.

The Program. The examined nonprofit program is now in its ninth year and is located in a large, mid-western urban city. The cohort learns 22 leadership/life skills. The current curriculum is focused on both leadership and life skill development in areas such as: Fatherlessness, Apologies, Trust, Love, Friendship, Goal Setting, Mentoring, Sex/Dating, Conflict Resolution, Anger Management, Communication, Hygiene/Dress, Employment, Recreation, A Father's Influence, Personal Identity, Your Legacy, Discouragement, Goal Setting, Public Speaking, Finances, and then concludes with a Rite of Passage. The program's founder also grew up as a child whose life was being destroyed as he searched for the love and guidance 
of a father. Over the past 15 years, the program's founder has traveled across the country helping men realize that the life that they are living today is the legacy that they are leaving for tomorrow by providing structured, leadership training to fatherless youth and adult men. To date, over 300 fatherless youth have taken part in this program. In the Fall of 2017, the program will welcome 25 new participants searching for life skills, mentoring, vision, character development, and leadership training. Following the completion of this project, the collected data were appropriately shared with the program's founder. The key themes reinforced the ongoing leadership learning process for this group of at-risk, inner city youth through a common denominator of effective mentorship.

Mentors. Effective mentors are vital to a youth leadership program and to other youth development initiatives (DuBois, Halloway, Valentine, \& Cooper, 2002; Miller, 2011; Owens, 2013; Royse, 1998; Woodland, 2014; Woodland, 2008). Generally speaking, most adolescents have mentors in their lives (Zimmerman, Bingenheimner, \& Notaro, 2002). Mentors help to moderate interpersonal problems, social welfare, and relationships (DuBois, Halloway, Valentine, \& Cooper, 2002; Zimmerman, Bingenheimner, \& Notaro, 2002). Clearly, exposure to caring adults who are invested in fostering development in an at-risk adolescent learner can decrease negative behaviors (DuBois, Halloway, Valentine, \& Cooper, 2002; Keating, Tomishima, Foster, \& Alessandri, 2002). Keating, Tomishima, Foster, \& Alessandri (2002) outlined that in a sixmonth period mentors provided lasting positive outcomes for participants. The mentors in this research project accompanied the cohort through the entire six months of training. Still, a key indicator in leading others may be serving others (Baughman \& Bruce, 2011; Buschlen \& Reusch, 2016; Horstmeier \& Ricketts, 2009).

Serving Others. While mentors provide an ongoing, and at times a lifetime commitment to the development of others, their time spent can best be viewed as service to the community. The feelings associated with serving others can lead to an increase in emotional intelligence, and represent a powerful facet of the leadership process (George, 2000; Zimmerman, Bingenheimer, \& Motaro, 2002). One who aspires to lead must be able to understand and manage the moods and emotions in one's self and in others (McCleskey, 2014). Barbuto \& Wheeler (2006) outlined a few simple questions to determine whether or not one's service mattered. The questions revolved around whether or not the person became a more well-rounded individual. Is the person in a stronger situation as a result of the services rendered? In addition, are they more likely to serve again? Buschlen and Reusch (2016) outlined that serving others inspired more service and had the potential to change one's worldview. When one pushes him or herself to become better while serving others, they begin to fulfill aspects found in social change leadership (Barbuto \& Wheeler, 2006).

\section{Social Change Model of Leadership}

The social change model of leadership was initially designed to serve as both a curriculum and a co-curriculum model for leadership education (HERI, 1996). As a data collection tool, the SCML can be used both qualitatively and quantitatively. For this project, the SCML model was used as a thematic framework to outline interview questions and then used to examine the transcripts. Questions were developed regarding self, teams, and how the young adults focused on lasting positive social change. The SCML (see Figure 1) was created to 
showcase student development of Individual values (self), Group values (team), and Community values (citizenship), all leading to a positive, lasting social change (Astin, 1993; HERI, 1996).

The SCML outlines the Seven C's of leadership through key tenets such as social justice, equality, self-worth, enablement, fellowship, responsibility, and service for others (HERI, 1996).

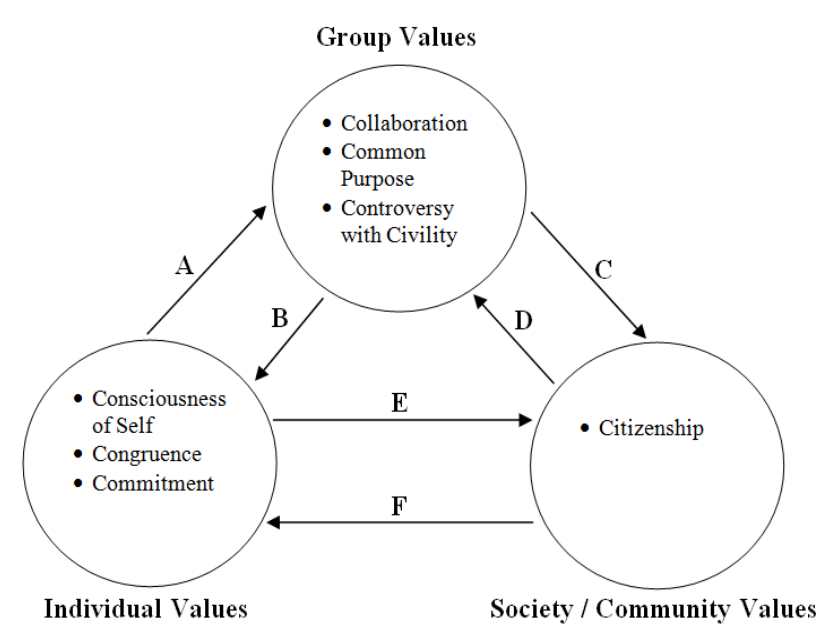

Figure 1.

Social Change Model of Leadership

Adapted from the Higher Education Research Institute (HERI, 1996)

Individual Values (Self). This aspect promotes three of the Seven C's: Consciousness of Self (awareness), Congruence (actions align with beliefs), and Commitment (continuous personal investment). Understanding one's self is the core of the SCML (Dugan \& Komives, 2007). Students who are more self-aware are likely to be attentive and have an ability to detect their own deeds(s) and sentient thoughts (Astin, 1993).

Group Values (Team). Teamwork is the next aspect and is outlined with three additional C's: Collaboration (collectively solving issues), Common Purpose (knowing the goal), and Controversy with Civility (amicably solving differences). This SCML feature underscores the model's reliance on teams that work to achieve common goals, share obligations, accountability, and influence (Buschlen \& Johnson, 2014). Therefore, each team member conveys a unique perspective that may or may not align with the group's direction (Dugan \& Komives, 2007). As a result, it is vital to a group's achievement that disagreements are steadied in an open forum (Astin, 1993).

Citizenship Values (Community). The final SCML construct is Citizenship. This aspect connects both the individual and/or the group to a larger, external community by 
understanding and appreciating the interconnectivity of a community (Astin, 1993). Citizenship implies active participation in serving the larger community and the need to care for others (Astin, 1993). The overarching value of the model is change, which asserts participants believe they have the ability to create lasting, positive social change. To further understand whether or not the alumni of the program have exhibited lasting, positive social change, participant answered a series of questions framed using the SCML. The long interview process with individual subjects allowed for a deep reflection. The subsequent focus group assisted the participants in correcting their individual construction of knowledge to a team focus. This process of reflection is key in both academic leadership programs and co-curricular programs (Buschlen \& Guthrie, 2014).

Many youth leadership programs or after school programs, tend to survey for satisfaction as a data collection method. This project sought to look more deeply at personal narratives and then report the reflective stories of alumni regarding the program's efficacy and lasting programmatic lessons that surpassed the initial leadership educational setting. The section that follows will outline the methodology and project participants.

\section{Methodology}

To understand the individual and shared experiences through the examination of participant narratives, the research team chose to implement transcendental phenomenology (Creswell, 2013). Phenomenology reduces many shared experiences down to a universal set of themes (Creswell, 2013). When implementing transcendental phenomenology, researchers deeply examine the phenomenon, remove their own connection to it as much as possible, and collect several narratives from those who experienced the phenomenon (Moustakas, 1994). For this study, the phenomenon focused on alumni who had completed a leadership education program as an adolescent. Alumni personal reflections and narratives were recorded and then examined by the research team. This form of qualitative investigation allows for a thoughtful understanding of both an individual and a shared experience. As a research method, this is prescribed to work well with groups of 5 to 25 individuals who have shared the same experience (Polkinghorne, 1989). This project outlines narratives of 10 participants. The personal narratives were examined using a phenomenological lens and then coded by each member of the research team. The data were examined for key themes following the coding process.

Context. The interviews and subsequent focus groups took place in a private conference room area at the main office of the organization. Individual interviews were conducted with one researcher and one alumni behind a closed door. The focus group included the research team and four alumni.

Participants. Ten male participants made up the sample $(n=10)$, ranging in age from 18 23 years old. Eight men were African-American, one was Mexican-American, and one was Caucasian. All were from the same mid-western city. Prior to the data collection, the research team met with the founder and president of the organization several times, but did not meet with any participants prior to the interview dates. These initial meetings with the founder focused on the functionality of the program, curriculum, and how best to recruit past alumni. The founder did not share personal alumni stories during these meetings, to help maintain researcher subjectivity. 
Data Collection Methods. The research team used recording software from Rev.com to record the audio portion of the interaction. The audio files were submitted and transcribed by Rev.com. The researcher did not refer to individuals by names during the recording session. During the focus group, the interactions were not recorded. Instead, the research team kept notes individually and then compared notes following the session to enhance credibility.

Data Analysis. Data files were transcribed by Rev.com and then edited by the research team to fill in inaudible gaps (outlined by the Rev.com report). To increase the dependability of the data set, the research team coded data individually and placed data into several theme piles. Then, the research team met to discuss their individual findings and examined the data set for interconnected themes. The research team implemented interrater reliability for this project (Creswell, 2013), which included an ongoing, open discussion to exchange and negotiate agreement on the final set of themes (Creswell, 2013). There were no major differences regarding broad concepts. However, further debate focused on emerging key themes. While at first, appearing to fit thematically, the research team did differ semantically with jargon. To achieve compromise, raters agreed upon a common vocabulary to increase reliability. A small number of incongruities were eliminated to produce the final set of shared experiences. Following this process, a small group of interviewees were reconvened and the research team shared the outcomes to further enhance data triangulation and credibility (Mills, 2010). This process included four participants and all three researchers. During the focus group, initial questions were revisited. Then, the research team shared the final set of themes and sought congruence from the group. The research team then examined notes from the event and collectively outlined the final set of themes.

To increase dependability of this data collection, the questions were based on previous data collection, which also implemented the SCML as a lens (Buschlen \& Reusch, 2016). It is assumed that this data set is unique. The data may or may not match past or future alumni responses to similar questions in this program or other similar programs.

\section{Findings}

The motivation behind this project was to examine student narratives from alumni to further understand a program's efficacy and to determine if there were any lasting impacts. Participant responses provided grounded data based on their individual, group, and community experiences before the program, while in the program, and now in their current life. The table that follows (see Table 1) will outline key quotes linked to each particular SCML element: individual, group, and community while reporting a variety of interrelated stories. 
Table 1. Participants Align with SCML Tenets

Understanding "Self"

\begin{tabular}{ll}
\hline SCML Construct & \multicolumn{1}{c}{ Quote } \\
\hline Consciousness of Self & "As I look back, I just didn't have any sense of who I was." \\
& "I was hesitant to join the program at first. I expected it not \\
to work, instantly. Later, it became an important thing for \\
me to go. \\
"This program showed me how to be a better person and \\
live it. Now I can consider myself, on a scale of 1 to 10, a \\
10. I started 1, 2 or 3."
\end{tabular}

\section{Understanding "Groups"}

\begin{tabular}{ll}
\hline SCML Construct & Quote \\
\hline Collaboration & $\begin{array}{l}\text { "The program promoted teamwork through group } \\
\text { activities and that instilled trust in one another. We all } \\
\text { needed that." } \\
\text { "We were all active with things together; no one was on } \\
\text { the bottom; everyone was equal." } \\
\text { "We were a team, and that was something that I wanted to } \\
\text { be a part of, a team, a family." }\end{array}$ \\
\hline
\end{tabular}

\section{Understanding "Citizenship"}

\begin{tabular}{ll}
\hline SCML Construct & Quote \\
\hline Citizenship & $\begin{array}{l}\text { "The world would be different if everyone cared about } \\
\text { others and not just self. I've been giving back like I was } \\
\text { supposed to" }\end{array}$ \\
Change & $\begin{array}{l}\text { "Being a leader is not about being served, but to serve. } \\
\text { What you give out, you get back." }\end{array}$ \\
\hline
\end{tabular}

\section{Thematic Connections}

Participants reported a violent life, poor communication skills, and ineffective decisionmaking skills, suicidal tendencies, along with trust and anger issues toward men. A subject in 
this study reported, "(before the program) . . . my life was a mess, I was a fighter and I skipped school. My dad was gone. I didn't really solve anything without anger. I was a very angry individual." Additional testimony revealed a predisposition that the program would fail the subjects, like other programs that were guided by men. The subjects were also surprised by the sheer number of youth in the program and by how they all shared a common story. A key precept of the curriculum is to learn to forgive fathers/men. One reported, "The program taught us to forgive, and our blessings stop if we don't forgive." When asked to reduce their experiences down to a few words, the most commonly used words were: forgiveness, caring/love, self-worth, and goal setting. The program's founder played an enormous role in developing and maintaining relationships with the young men. Key factors reported, after the intervention, outline that the young men were inspired to serve others as a result of being served. Not all have chosen fatherlessness as a cause, but all have chosen a cause. With regards to the program, seven of 10 have already served as a mentor, giving back to the program that had given them so much. The following themes were examined in three phases to complement the interview format: life before the program, life during the program, and life today.

Understanding Self. The fundamental SCML finding before the young men entered the program was a fatherless, angry life filled with chaos, more specifically they had very limited knowledge of self or self-worth. Many of the young men used violence or physical aggression as a means to solve problems. All reported poor communication skills that often led to violent interactions. Some played sports, but had a hard time maintaining grades. While unsolicited information, two subjects admitted to being suicidal prior to entering the program. One went as far as placing the gun to his head as a middle schooler. He said, "oh well, that was the hand I was dealt and I had to survive (or not)." Understanding one's "self" is significant to one's ability to function in the other facets of the SCML (Buschlen \& Dvorak, 2011; Dugan \& Komives, 2007). Komives et al. (2005) suggested that understanding the latter two (groups and citizenship) required a deeper, more critical understanding of leadership found in highly developed individual, those who clearly understand who they are. The young men then, needed something that was missing:

I was just really bad at problem solving. I don't know, I didn't really solve anything without anger. I was a very angry individual. I just didn't have any sense of identity. I just felt as if ... I'm fatherless, so I just felt as if I was just out there. I was just kind of spiraling, but yeah, just kind of spiraling.

I did not cope with problems, kept them inside - I had the tendency for physical violence. I was a fighter.

I remember one day, I found a gun in her dresser. It wasn't loaded at all, no clip in there. On the dresser there's the mirror, and I'd stare at myself in the mirror every time I pulled the gun out. Looking at myself in the mirror, I tried to imagine myself pulling the trigger. Then I start to think, "Okay, well, who would miss me?" I started to go down the list, I got my great-grandma, my grandma, my grandpa. Think about all the friends that I got. I remember putting the gun up to my head and I tried to pull the trigger, and I just couldn't do it. Until one day I decided to do it, knowing the gun wasn't loaded. Knowing it wasn't loaded, I just ... I don't know, this is a dark time in my life. 
I had all these different men try to come speak to me before, "You should do this and do that," and I was at the time in my life where suicide was just pretty much the gateway. That was the only thing on my mind. I can't get along with my family. I'm in conflict with my mom, my brother. I'm not succeeding anywhere, any field in my life, and I'm like ... something's got to give.

Leadership Program Expectations. When asked about their expectations prior to joining the program, a clear pattern emerged regarding the self-realization that fatherlessness is a problem beyond just their experience:

When I walked in there was a room full of people, I was surprised! We were at a nature center so it is a really big area and there was probably about thirty, thirty-five people there and I was just surprised by that. I thought it would have been like ten, fifteen people at the most but what took me by surprise is that there are so many kids that related to me and they had it worse than me.

I think the fact that there were so many people there. I didn't expect it to be almost a room full with older mentors there too. I was expecting like maybe 5 people.

I was surprised by the amount of kids in the program, honestly. It kind of bothered me. When I came in, we were deep. I think we were 40, 50 deep at the time. Yeah, just the sheer numbers. I say the numbers because they're all, not the same, but similar stories to myself. It's a shame, to be honest.

In Leadership Education, the Educator Matters. A key finding that emerged was the authentic qualities reported regarding the program's founder. Not only was he a leadership educator, but he became their symbolic father and to some, their savior. Subjects often gave credit to their life path and current worldview to the role modelling and actions exhibited by the founder. The program director modeled sympathy, empathy, and the tough love they needed from a man they learned to trust while learning to forgive past failures. The program's founder invested in their life, devoted time to their future, and dedicated his life to breaking the cycle of fatherlessness:

I can relate to him. We relate very, very well. It's like he's an older version of me, in a sense, because the things that I went through, he went through the same thing. The same cycle, the very same story. When I sat down with him, it was like he understood every step of my story, and before I knew it I just kept talking and everything just came out and he's been there every step of the way "I've been there. I understand what you're going through." You get around him, his being, it just makes you want to be a better person.

I stood outside in the parking lot and my mom introduced me to him. I shook his hand and he said, "Hey, nice to meet you," and she said this man is going to change your life and will look out for you. 
He sets the standard. Beautiful house, wife, car, kids. I want all of that. We all wanted all of that. I knew I would never reach it if I stayed bitter, holding onto the past, holding onto this pain and hurt and using this, "I didn't have a father. He didn't teach me" as an excuse in moving forward, so I can have these things by forgiving myself, and loving myself.

He knew how it felt. I was the only one in my family without a dad. It was awesome because he took us to football games. I don't know, it was just really cool because he was just always welcoming. Every time you saw him he was happy as could be. I wanted that, because I thought if he could do it I could do it.

When I was 17, I got sentenced to jail, and no one came and visited me except him. He was the only one that came in every week, every week I could count on him to be there. That was after my grandfather passed away, and he was the only father figure I had. It meant the world to me, because it was winter, it was back in December, and he came and visited me. He didn't have to do that, and he made time for it every week. I don't know, it just showed me that he really, really cared.

There was a couple times around Christmas time, he dropped off a Christmas basket for me. Then there was a time where he was taking me out to eat just to talk to me and catch up, and see how everything's doing. He was always there. Whenever I needed him I could just call him up and he would talk to me. I had a father.

Understanding Teamwork. While in the program, young men are engaged in a curriculum designed to teach them 22 leadership/life skills. Many of the lessons relate to communication as a member of team. Based on their testimonies, the young men in the program quickly figured out that they are not alone:

Everything was team building. You can't raise a child by yourself. It takes a village, and team building skills allowed us to laugh, communicate, and really open up, really open up and get to know each other and being confident when you speak and look people eye to eye and be authoritative, and just pretty much teach you how to be a team player.

We actually did a confidence course. We had to help each other out. We had to build each other up ... I'm like, "I'm not doing that. I'm not going to swing on that rope. I'm just not going to swing on the rope." They built me up, and encouraged me that you can do it, you can be on the rope.

That's where we got like a group "we can help each other, we can grow." That even sprouted out into our life, our regular lives. We still have a relationship to this day. Yeah, it showed our shared purpose. Once we came out of the program and saw our progression, we were like, "Wow, this really worked. It really worked."

Yeah, we all played football in the parking lot, and it just kind of showed that if you want it to work out you have to work as a team. It was cool because he had a bunch of little things, but they all showed teamwork, that it's not all about you it's about everyone else. 
I'm better at caring for people, and understanding people. I learned teamwork, respect for others, and the program showed me how to be a better person.

For some, teamwork is still pervasive in their daily lives. The program has even influenced their communication skills:

The teamwork aspect is definitely important. I'm a big team player. I was a point guard so I had to facilitate and build the team atmosphere. Now in college, like group projects, I'm normally the guy that says, "This is how we're going to do it. We're going to get it done." I take into account others feelings, the sympathy, empathy part. After the program, I can understand where people are coming from better now. I don't jump to conclusions. I think it out first, maybe he or she felt this way, that's why she did it. I feel like I'm just a better overall, decision maker.

I've gone from a knucklehead to being more mature. Really just learning to communicate better, pretty much. When I say that, I mean in all aspects. Learning to even recognize a situation before it happens and then just going off of decision factors on either how to avoid that or calm the situation down.

Understanding Community. Another finding from this project outlined how the leadership lessons learned in this program transcended the setting and intertwined these young men within their larger community. In fact, while a few of the young men stated they served their church as a greeter (or similar role) before the program, all of the young men are now serving others and clearly connected their service to their time in the program. Providing lasting social change for the community is the final tenet of the SCML:

I want to give back. I want to teach others what I was taught, and I want to see others come through and come out of what I came out of.

I mentor young kids and teach them certain principles that I've learned from this program. They love it. They listen, which makes me want to keep teaching them and giving them words of wisdom and inspiring them to do better and telling them that you're important, that you matter.

When I was at college, I used to help out the homeless, feed them and just give everything away, without question. In the winter time we go out and we shovel snow.

I was helping the kids out at the daycare at my church and trying to teach them about the bible and how to play like a team.

One example would be for my graduation from high school, along with my open house I had a food and supply drive for the city rescue mission. 
A majority, seven out of 10, have returned to the program as a mentor. Five of the 10 have gone on to college. Many of them articulated key features of outstanding mentorship, reflective of their own experiences as a mentee:

A good mentor should lead by example, definitely. That's a big one. They should also be confident in what he or she is saying. Just be able to break the ice with the kid or the mentee. Be able to initiate conversation, initiate it because the mentee might not necessarily want to be mentored, but needs to be mentored.

You've got to have love first. That's number one. I stand by it. You've got to have confidence. Got to be authoritative. You've got to mean what you say. You've got to believe what you say. If you believe what you say, then somebody will believe you.

Be open with someone, be caring, have an ear to listen, too, and just be patient. Be a good example, be a graduate from program, and always take the high road.

Somebody that's well-rounded. Someone who can understand your low point, your high point, and your middle point. Someone who can understand. I was there with you. I understand where you're coming from. You have to be able to understand people.

They're loving people, they all care about us, they all go out of their way selflessly, they give more than they have to. They took care of us, and they understood everything.

Transcendent Leadership Lessons. Similar to developing a desire to serve others, which emerged as an outcome following participation in the program, the group reported a deeper understanding of leadership. While leadership theory was not formally taught, the pragmatic leadership lessons propelled these young men forward into a paradigm of communitybased, selfless leadership:

Sympathy and empathy, the understanding, that's the big thing about being leader, a big key about being a leader. You get to see where others are coming from, understand why they're doing it and try to explain to them, using the communication that you learned.

Be the example. Bottom line. If you want to see change, or if you want change to happen in an environment around where the people, be that example. As a leader, you got to get up and go. Leadership is, I would say ... is being an example.

If I did something wrong, I would admit to it, and I would apologize and be a man about my mistakes, and hopefully that teaches the person next time to own up to your mistake, because it's up to the person.

Not everyone is even, not everyone gets the same thing. You just got to realize that that's how life is and you just got to move on with it. Leadership skills are how to deal with people. An important part of being a leader, I believe, is knowing how to deal with people. 
Leadership is very powerful. I can manifest whatever I want throughout my thoughts. I just have to believe in myself. I have to believe in it so it becomes real. If I can't see it, I can't reach it. I can't touch it. If you can see it and believe it, it will happen, so the manifestation is real. It is real.

The participants in this program, by means of the curriculum and setting, developed a strong sense of self, which resulted in stronger communication skills through a team-focused format, while more deeply understanding the benefits of creating positive social change in their communities. Both the service they benefitted from and the lessons learned in the program have transcended the program and many of the students have now become teachers or mentors.

\section{Discussion}

The process of social change leadership development is an inclusive one (Buschlen \& Guthrie, 2014). The development of community-minded leaders requires a lens that focuses on self, communal awareness, team engagement, integrity, and service to others (Dugan, 2006, Jacob, 2006; Komives, Owen, Longerbeam, Mainella, \& Osteeen, 2005). These SCML experiences tend to lead to a more heightened sense of personal transformation (Buschlen \& Reusch, 2016) and in this case, lessons which transcend the initial experience. In this case, mentoring provided an essential learning atmosphere where students understood pragmatic concepts and seemed to understand their role in the larger community. Eccles (2005) stated that voluntary youth participation in organized events and activities, such as the one outlined here, should reduce negative behaviors and support proper adjustment as an adult. While in this program, these young men developed forgiveness, empathy, and emotional intelligence (Berger \& Milem, 2002) as they developed their leadership identities and skills.

This project utilized the SCML as a lens to gauge self, teams, and community goals. The goal was to develop a thematic depiction of participant experiences who all shared a common experience (Creswell, 2013) by examining the efficacy and lasting impacts of this adolescent leadership development program for at-risk, inner city youth.

\section{Limitations}

This data collection captured a specific set of unique experiences, which may differ with future data collections. Therefore, this qualitative project did not seek to generalize findings, nor was this a goal or outcome of this project. Also, asking participants to recall information from the past while connecting it to their present limits the findings. Participants may develop a stronger, more favorable connection to this program over time, especially since many have returned as mentors. In future studies, complimentary quantitative data ought to be documented from adolescent boys currently in the program and compared over time to outline a more holistic outcome.

The level of participant awareness of the SCML prior to the data collection is unknown, but might be little or none. The research team implemented interview questions to examine self, teams, and community/citizenship of the subjects during their experiences in the program. It is assumed that the participants were never exposed to the SCML as a working curriculum. 


\section{Implications for Leadership Educators}

Formal leadership education continues to grow in both youth/adolescent systems and higher education systems. This project outlined the need for teachers to be authentic leaders first. Someone may deeply understand leadership theories, have a wonderful plan for teaching it, but may fall short of being believable as a leader. Similarly, being a wonderful leader will not automatically make you a great teacher. Someone must have both the knowledge and the leadership aptitude to relate to his or her students in a meaningful way. Hiring decisions for leadership educators should combine both a pragmatic assessment of what they have done as a leader along with what they know as a leadership educator.

In this project, service to others appeared to be both an intrinsic and extrinsic motivator to serve more. This project examined those being served and outlined that the service they received propelled them into serving others. Therefore, leadership educators need to be intentional, concerning service assignments. The process of serving others may have the power to entice more community engagement.

The social change model of leadership was not part of this program's curriculum. However, this project reinforced the applicable nature of this model as an exemplary leadership development tool, which can be used to examine other leadership development programs. The model's frugal tenets highlight the interconnectivity of self, teams, and community engagement, supporting the parsimonious nature of the SCML. Therefore, the model appears to be an ideal measure for examining leadership development through both formal education as well as through praxis.

\section{Conclusion}

Relatively speaking, life can be challenging for everyone. However, many endure additional life challenges, such as growing up without their biological father in the home. Growing up in this environment has broad sweeping impacts on society, yet some of these young men do amazing things while others continue to struggle. In this case, a six-month, cohort-based leadership program provided some with positive, lasting outcomes. The first revolved around serving others. More specifically, the service received from mentors inspired positive changes in themselves and their communities. The leadership learning seemed to transcend the program while the knowledge and lessons remained firmly with these young adults. Also, the program's founder became almost "savior-like" to the young men as he is now a lifelong mentor and positive change agent. Therefore, the selection of an authentic and qualified leadership educator proved vital to this program's success.

Leadership education has the potential to modify lives for the better as students are better equipped to develop into community minded individuals wishing to create lasting positive change. The stakes for leadership education and service have never been greater, as this project and others continue to outline how leadership education can change lives. More specifically, the program outlined in this project also saved lives . . . lives that matter to everyone. This fact alone increases the need for future youth leadership training endeavors. 


\section{References}

American Academy of Pediatrics (AAP). (2003). Family Pediatrics: Report of the Task Force on the Family. Pediatrics, 111(6), 1541-1571.

Anderson, J., Kim, E. (2009). Youth leadership development: Perceptions and preferences of urban students enrolled in a comprehensive agriculture program. Journal of Agricultural Education, 50(1), 8-20. DOI: 10.5032/jae.2009.01008

Arnold, P. P., \& Welch, M. (2007). Who we really are: Demographic factors that predict student service leadership. NASPA Journal, 44(1), 147-164.

Astin, A. W. (1993). What matters in college: Four critical years revisited. San Francisco: Jossey-Bass.

Barbuto, J. E., \& Wheeler, D. W. (2006). Scale development and construct clarification of servant leadership. Group \& Organizational Psychology, 72, 441-462.

Baughman, K. N., \& Bruce, J. (2011). The unique leadership needs of minority student populations: Crafting a leadership identity. Journal of Leadership Education, 10(2), 97-115.

Bean, E., Whitley, M. A., Gould, D. (2014). Athlete impressions of a character-based sports program for underserved youth. Journal of Sport Behavior, 37(1), 3-23.

Berger, J. B., \& Milem, J. F. (2002). The impact of community service involvement on three measures of undergraduate self-concept. NASPA Journal, 40(1), 85-103.

Bethea, S. L. (2012). The impact of Oakland Freedom School's summer youth program on the psychosocial development of African American youth. Journal of Black Psychology, 38(4), 442-454. doi: 10.1177/0095798411431982

Bishop, J., \& Lane, R. C. (2000). Father absence and the attitude of entitlement. Journal of Contemporary Psychotherapy, 30(1), 105-117. doi:10.1023/A:1003657300883.

Blum, R. W., Beuhring, T., Shew, M. L., Bearinger, L. H., Sieving, R. E., \& Resnick, M. D. (2000). The effects of race/ethnicity, income, and family structure on adolescent risk behaviors. American Journal of Public Health, 90(12), 1879-1884. doi:10.2105/AJPH.90.12.1879

Blundell, S. (2002). Psychoanalytic psychotherapy with bereaved boys. In A. Etchegoyen \& J. Trowell (Eds.), The Importance of Fathers. A Psychoanalytic Re-evaluation (pp. 172-185). Routledge.

Brown, S. L., \& Rinelli, L. N. (2010). Family structure, family processes, and adolescent smoking and drinking. Journal of Research on Adolescence, 20(2), 259-273. doi:10.1111/j.1532-7795.2010.00636.x. 
Bruce, W. H. (1973). A report on the design and the results of the Toronto study. Philadelphia, PA: Big Brothers/Big Sisters of America.

Brumbaugh, L., \& Cater, M. (2016). The perceived importance of youth educator's confidence in delivering leadership development programming. Journal of Leadership Education, 15(1), 1-14. doi: 1012806/V15/I1/R1

Buschlen, E. L. \& Dvorak, R. G. (2011). The social change model as pedagogy: Examining undergraduate leadership growth. Journal of Leadership Education, 10(2), 38-56.

Buschlen, E. L. \& Guthrie, K. L. (2014). Seamless leadership learning in curricular and cocurricular facets of university life: A pragmatic approach to praxis. Journal of Leadership Studies, 7(4), 65-71.

Buschlen, E. L. \& Johnson, M. R. (2014). The effects of an introductory leadership course on SRLS scores, examined by age and gender. Journal of Leadership Education, 13(1), 31-45. doi: 10.12806/V13/I1/R3

Buschlen, E. L. \& Reusch, J. R. (2016). The assessment of service through the lens of social change leadership: A phenomenological approach. Journal of College and Character, 17(2), 82-100. doi: 10.1080/2194587X.2016.1159224

Connolly, J., Josephson, W., Schnoll, J., Simkins-Strong, E., Pepler, D., MacPherson, A., Weiser, J., Moran, M., \& Jiang, D. (2015). Evaluation of a youth-led program for preventing bullying, sexual harassment, and dating aggression in middle schools. The Journal of Early Adolescence, 35(5), 403 - 434. doi:10.1177/0272431614535090

Connor, J. O., \& Strobel, K. (2007). Leadership development: An examination of individual and programmatic growth. Journal of Adolescent Research, 22(3), 275-297. doi: 10.1177/07 43558407299698.

Creswell, J. W. (2013). Qualitative inquiry and research design: Choosing among five approaches. $\left(3^{\text {rd }} \mathrm{ed}\right)$. Thousand Oaks, CA: Sage.

Curran, L. (2003). Social work and fathers: Child support and fathering programs. Social Work, 48(2), 219-227. doi:http://dx.doi.org/10.1093/sw/48.2.219.

Daugherty, R. A., \& Williams, S. E. (1997). The long-term impacts of leadership development: An assessment of a statewide program. Journal of Leadership \& Organizational Studies, 4(2), 101-115. doi: 10.1177/107179199700400210

DeBell, M. (2008). Children living without their fathers: Population estimates and indicators of educational well-being. Social Indicators Research, 87(3), 427-443. doi:10.1007/s11205007-9149-8 
DuBois, D. L., Holloway, B. E., Valentine, J. C.,\& Harris, C. (2002). Effectiveness of Mentoring Programs for Youth: A Meta-Analytic Review. American Journal of Community Psychology, 30(2), 157-197. doi: 10.1023/A:1014628810714

Dugan, J. P. (2006). Explorations using the social change model: Leadership development among college men and women. Journal of College Student Development, 47(2), 217-225.

Dugan, J. P., \& Komives, S. R. (2007). Developing leadership capacity in college students: Findings from a national study. A report from the multi-institutional study of leadership. College Park, MD: National Clearinghouse for Leadership Programs.

Eccles, J. S., Barber, B. L., Stone, M., \& Hunt, J. (2003). Extracurricular activities and adolescent development. Journal of Social Issues, 59(4), 865-889.

Eich, D. (2008). A grounded theory of high-quality leadership programs: Perspectives from student leadership development programs in higher education. Journal of Leadership \& Organizational Studies, 15(2), 176-187. doi: 10.1177/1548051808324099

Eva, N., \& Sendjaya, S. (2013). Creating future leaders: an examination of youth leadership development in Australia. Education + Training, 55(6), 584-598. http://dx.doi.org/ 10.1108/ET-08-2012-0082

Frecknall, P., \& Luks, A. (1992). An evaluation of parental assessment of the Big Brothers/Big Sisters program in New York City. Adolescence, 27, 715-718.

George, J. M. (2000). Emotion and Leadership: The Role of Emotional intelligence. Human Relations, 53, 1027-1055.

Guerin, D. W., Oliver, P. H., Gottfried, A. W., Gottfried, A. E., Reichard, R. J., \& Riggio, R. E. (2011). Childhood and adolescent antecedents of social skills and leadership potential in adulthood: Temperamental approach/withdrawal and extraversion. Leadership Quarterly, 22(3), 482-494. doi: 10.1016/j.leaqua.2011.04.006

Guthrie, K. L., \& Thompson, S. (2010). Creating meaningful environments for leadership education. Journal of Leadership Education, 9(2), 50-57.

Hancock, D., Dyk, P. H., \& Jones, K. (2012). Adolescent involvement in extracurricular activities: Influences on leadership skills. Journal of Leadership Education, 11(1), 84-101.

Hansen, D. M., Larson, R. W., \& Dworkin, J. B. (2003). What adolescents learn in organized youth activities: a survey of self-reported developmental experiences. Journal of Research on Adolescence, 13(1), 25-55.

Hastings, L. J., Barrett, L. A., Barbuto, J. E., \& Bell, L. C. (2011). Developing a paradigm model of youth leadership development and community engagement: A grounded theory. Journal of Agricultural Education, 52(1), 19-29. doi: 10.5032/jae.2011.01019 
HERI. (1996). A social change model of leadership development, guidebook III. Los Angeles, CA: Higher Education Research Institute.

Hicks Peterson, T., Dolan, T., \& Hanft, S. (2010). Partnering with youth organizers to prevent violence: An analysis of relationships, power, and change. Progress in Community Health Partnerships: Research, Education, and Action, 4(3), 235-242. doi: 10.1353/cpr.2010.0011

Higham, R., Freathy, R., \& Wegerif, R. (2010). Developing responsible leadership through a 'pedagogy of challenge': An investigation into the impact of leadership education on teenagers. School Leadership and Management, 30(5), 419-434. doi: 10.1080/1363243 4.2010 .525229

Hine, G. S. (2012). Exploring the need for improvement in a student leadership program. Journal of Catholic Education, 84(1), 12-22. Retrieved from http://researchonline.nd.edu.au/edu article/97

Hine, G. S. (2014). Student leadership development: A functional framework. Journal of Catholic Education, 18(1), 79-110. doi: 10.15365/joce.1801052014

Horstmeier, R. P., \& Ricketts, K. G. (2009). Youth leadership development through school-based civic engagement activities: A case study. Journal of Leadership Education, 8(2), 238-253.

Jackson, I., Sealey-Ruiz, Y., \& Watson, W. (2014). Reciprocal love: Mentoring Black and Latino males through an ethos of care. Urban Education, 49(4), 394-417. doi: $10.1177 / 0042085913519336$

Jacob, A. (2006). Implementing effective leadership development programs for community colleges. Retrieved October 27, 2006, from http://www.eric.ed.gov/PDFS/ED492857.pdf

Keating, L. M., Tomishima, M. A., Foster, S., \& Alessandri, M. (2002). The effects of mentoring program on at-risk youth. Adolescence, 37(148), 717-34.

Komives, S. R., \& Dugan, J. P. (2014). Student Leadership Development. The Oxford Handbook of Leadership and Organizations. doi: 10.1093/oxfordhb/9780199755615.013.039

Komives, S. R., Lucas, N., \& McMahon, T. R. (1998). Exploring leadership: For college students who want to make a difference. San Francisco, CA: Jossey-Bass.

Komives, S. R., Owen, J. E., Longerbeam, S. D., Mainella, F., C., \& Osteeen, L. (2005). Developing a leadership identity: A grounded theory. Journal of College Student Development, 46, 593-611.

Kress, C. A. (2006). Youth leadership and youth development: Connections and questions. New Directions for Youth Development, 2006(109, 45-56. doi: 10.1002/yd.154 
Lapierre, L. M., Naidoo, L. J., \& Bonaccio, S. (2012). Leaders' relational self-concept and followers' task performance: Implications for mentoring provided to followers. Leadership Quarterly, 23(5), 766-774. doi: 10.1016/j.leaqua.2012.01.001

Larson, R. W., \& Tran, S. P. (2014). Invited commentary: Positive youth development and human complexity. Journal of Youth and Adolescence, 43(6), 1012-1017. doi: 10.1007/s 10964-014-0124-9

Larson, R., Walker, K., \& Pearce, N. (2005). A comparison of youth-driven and adult-driven youth programs: balancing inputs from youth and adults. Journal of Community Psychology, 33(1), 57-74. doi: 10.1002/jcop.20035

Leff, S. S., Baker, C. N., Waasdorp, T. E., Vaughn, N. A., Bevans, K. B.m Thomas, N. A., Guerra, T., Hausman, A. J., \& Monopoli, W. J. (2014). Social cognitions, distress and leadership self-efficacy: Associations with aggression for high-risk minority youth. Development and Psychopathology, 26(3), 759-772.

Libby, M., Rosen, M., \& Sedonaen, M. (2005). Building youth-adult partnerships for community change: lessons from the Youth Leadership Institute. Journal of Community Psychology, 33(1), 111-120. doi: 10.1002/jcop.20037

Libby, M., Sedonaen, M., \& Bliss, S. (2006). The mystery of youth leadership development: The path to just communities. New Directions for Youth Development, 2006(109), 13-25. doi: 10.1002/yd.152

MacNeil, C. A. (2006). Bridging generations: Applying "adult" leadership theories to youth leadership development. New Directions for Youth Development, 2006(109), 27-43. doi: 10.1002/yd.153

Mahoney, J. L., Larson, R. W., Eccles, J. S., \& Lord, H. (2005). Organized activities as developmental contexts for children and adolescents. Organized activities as contexts of development: Extracurricular activities, after-school and community programs, 3-22.

McCleskey, J. (2014). Emotional intelligence and leadership. International Journal of Organizational Analysis, 22(1), 76-93. doi: http://dx.doi.org/10.1108/IJOA-03-2012-0568

Miller, P. M. (2012). Community-based education and social capital in an urban after-school program. Education and Urban Society, 44(1), 35-60. doi:10.1177/0013124510380910

Mills, G. E. (2010). Action research: A Guide for the teacher researcher ( $3^{\text {rd }}$ ed.). Merrill/Prentice-Hall: Upper saddle River, NJ.

Moustakas, C. (1994). Phenomenological research methods. Thousand Oaks, CA: Sage. 
Mumford, M. D., \& Manley, G. G. (2003). Putting the development in leadership development: Implications for theory and practice. In Murphy S., Riggio R. (Eds.), The future of leadership development (pp. 237-262). Mahwah, NJ: Erlbaum.

Mumford, M. D., Marks, M. A., Connelly, M. S., Zaccaro, S. J., \& Reiter-Palmon, R. (2000). Development of leadership skills: Experience and timing. The Leadership Quarterly, 11(1), 87-114.

O’Donoghue, J. L., \& Strobel, K. R. (2007). Directivity and freedom: adult support of activism among urban youth. American Behavioral Scientist, 51(3), 465-485. doi: 10.1177/ 0002764207306071

Oliver, P. H., Gottfried, A. W., Guerin, D. W., Gottfried, A. E., Reichard, R. J., \& Riggio, R. E. (2011). Adolescent family environmental antecedents to transformational leadership potential: A longitudinal mediational analysis. The Leadership Quarterly, 22(3), 535-544. doi: 10.1016/j.leaqua.2011.04.010

Oman, R. F., Vesely, S. K., \& Aspy, C. B. (2005). Within the context of family structure. American Journal of Health Behavior, 29(6), 557-568.

Owen, J. E. (2012). Findings from the Multi-Institutional Study of Leadership Institutional Survey: A National Report. College Park, MD: National Clearinghouse for Leadership Programs.

Owens, M. A. (2013). "The feeling's mutual”: Student participation in leadership as a cooperative effort. The Review of Higher Education, 36(4), 435-462. doi: 10.1353/rhe.2013.0053

Palmer, R.T., Maramba, D.C. \& Holmes, S.L. (2011). A contemporary examination of factors promoting the academic success of minority students at a predominantly White institution (PWI). Journal of College Student Retention, 13(3), 329-349.

Polk, D. M. (2013). Cultivating self-awareness with team-teaching: Connections between classroom learning and experiential learning. Journal of Leadership Education, 12(2), 122135.

Polkinghorne, D. E. (1989). Phenomenological research methods. In R. S. Valle \& S. Halling (Eds.), Existential-phenomenological perspectives in Psychology. (pp. 41-60). New York, NY: Plenum Press.

Priest, K. L., \& Donley, S. (2014). Developing leadership for life: Outcomes from a collegiate student alumni mentoring program. Journal of Leadership Education, 13(3), 107-117. doi: 1012806/V13/I3/A2

Rehm, C. J. (2014). An evidence-based practitioner's model for adolescent leadership development. Journal of Leadership Education, 13(3), 83-97. doi:1012806/V13/I3/T1 
Reichard, R. J., Riggio, R. E., Guerin, D. W., Oliver, P. H., Gottfried, A.W., \& Gottfried, A. E. (2011). A longitudinal analysis of relationships between adolescent personality and intelligence with adult leader emergence and transformational leadership. The Leadership Quarterly, 22(3), 471—481. doi:10.1016/j.leaqua.2011.04.005

Ricketts, J. C., \& Rudd, R. D. (2002). A comprehensive leadership education model to train, teach, and develop leadership in youth. Journal of Career and Technical Education, 19(1).

Rosch, D. M., Boyd, B. L., \& Duran, K. M. (2014). Students' self-identified long-term leadership development goals: An analysis by gender and race. Journal of Leadership Education, 13(3), 17-33. doi: 1012806/V13/I3/R2

Rose, P. (2010). Transformational leadership and its relationship to adult 4-H volunteers' sense of empowerment in youth development settings. Journal of Leadership Education, 9(2), 5871.

Royse, D. (1998). Mentoring high-risk minority youth: Evaluation of the brothers project. Adolescence, 33(129), 145-158.

Saintonge, S. (1987). Les modeles d'identification dans l'identite de l'adolescent: Etude d'un cas [Identification models in male adolescent identity: Case study]. Unpublished master's thesis, Universite de Montreal, Montreal, Quebec, Canada.

Sessa, V. I., Morgan, B. V., Kalenderli, S., \& Hammond, F. E. (2014). Key events in student leaders' lives and lessons learned from them. Journal of Leadership Education, 13(2), 1-28. doi: 10.12806/V13/I2/R1

Swigert, T., \& Boyd, B. L. (2010). The impact of Boys \& Girls Club/Keystone Club participation on alumni. Journal of Leadership Education, 9(1), 69-86.

Wisniewski, M. A. (2010). Leadership and the millennials: Transforming today's technological teens into tomorrow's leaders. Journal of Leadership Education, 9(1), 53-67.

Woodland, M. H. (2008). Whatcha doin' after school?: A review of the literature on the influence of after-school programs on young black males. Urban Education, 43(5), 537-560.

Woodland, M. H. (2014). After-school programs: A resource for young black males and other urban youth. Urban Education, 1-27. doi: 10.1177/0042085914549361

United States Census (2015). America's Families and Living Arrangements: 2015. Retrieved from http://www.census.gov/hhes/families/data/cps2015.html.

Zimmerman, M. A., Bingenheimer, J. B., \& Notaro, P. C. (2002). Natural Mentors and Adolescent Resiliency: A Study with Urban Youth. American Journal of Community Psychology, 30(2), 221-243. doi: 10.1023/A:1014632911622 


\section{Authors}

Eric Buschlen, Ed.D., is an Associate Professor in the Department of Educational Leadership at Central Michigan University. His research interests include service to others as leadership, strategic mechanisms for academic and student affairs assessment, social change leadership, and youth leadership development. Dr. Buschlen earned his doctorate in Educational Leadership from Central Michigan University. busch1el@cmich.edu

Tzu-Fen Chang, Ph. D., is an Assistant Professor in the Department of Human Environmental Studies at Central Michigan University. Her research interests include the ways in which family, community, school contexts, and culture influence psychosocial and educational adjustment of children and adolescents. Dr. Chang received her doctorate in Human Development and Family Studies from Michigan State University. chang1t@cmich.edu

Dena R. Kniess, Ph.D., is an Assistant Professor in the Department of Counselor Education and College Student Affairs at the University of West Georgia. Her research interests include assessment, college access and student success, faculty transitions, and multicultural issues. Dr. Kniess received her doctorate in Educational Leadership - Higher Education from Clemson University. dkniess@westga.edu 